\title{
Growth and DNA damage in young Laminaria sporophytes exposed to ultraviolet radiation: implication for depth zonation of kelps on Helgoland (North Sea)
}

Received: 11 May 2005/ Accepted: 22 September 2005/Published online: 24 November 2005

(C) Springer-Verlag 2005

\begin{abstract}
Growth as an integrative parameter of all physiological processes was measured in young sporophytes of temperate Laminaria digitata, Laminaria saccharina and Laminaria hyperborea exposed in the laboratory to irradiance consisting of either only photosynthetically active radiation (PAR) or to a spectrum including ultraviolet radiation (UVR) (PAR + UVA + UVB) by use of cut-off glass filters. Size increment was measured every $10 \mathrm{~min}$ over a period of 18 21 days using growth chambers with on-line video measuring technique. In the chamber, plants were grown at $10 \pm 2^{\circ} \mathrm{C}$ and $16: 8 \mathrm{~h}$ light-dark cycles with $6 \mathrm{~h}$ additional UVR exposure in the middle of the light period. Tissue morphology and absorption spectra were measured in untreated young sporophytes while chlorophyll a content and DNA damage were measured in treated thalli at the end of the experiment. Sensitivity of growth under UVR was found to be related to the observed upper depth distribution limit of the upper sublittoral $L$. digitata, upper to mid sublittoral $L$. saccharina and lower sublittoral L. hyperborea. Tissue DNA damage is, however, dependent on thallus thickness which minimizes UVR effect where outer cell layers shade inner
\end{abstract}

Communicated by O. Kinne, Oldendorf/Luhe

M. Y. Roleda ( $\square)$

Alfred Wegener Institute for Polar and Marine Research, Biologische Anstalt Helgoland, 27498 Helgoland, Germany E-mail: mroleda@awi-bremerhaven.de

Tel.: + 49-4725-819230

Fax: + 49-4725-819283

M. Y. Roleda

Biology Department, De La Salle University,

2401 Taft Avenue, 1004 Manila, Philippines

D. Hanelt

Biozentrum Klein Flottbek, University of Hamburg,

Ohnhorst-Str. 18, 22609 Hamburg, Germany

C. Wiencke

Foundation Alfred Wegener Institute for Polar and Marine Research, Am Handelshafen 12, 27570 Bremerhaven, Germany cells and provide longer pathlength for UVR. Exposure to UVR causes cellular, enzymatic and molecular damage. Presence of UV-absorbing compounds further reduces effective UVR from reaching physiological targets. The cost of producing higher amount of UV-absorbing compounds and effective DNA repair mechanism can, however, divert photosynthate at the expense of growth. Tissue chlorophyll a content was not significantly different between treatments suggesting a capacity for acclimation to moderate UVR fluence. Growth acclimation to repeated UVR exposure was observed within a period of 12 days while growth inhibition was observed after a longer UVR exposure period of 21 days. The results give further insight into the effects of UVR on the cellular level and show how ecological parameters such as the upper depth distribution limit are dependent on cellular processes.

\section{Introduction}

The three kelp species from Helgoland grow in characteristic belts with Laminaria digitata (Hudson) Lamouroux in the upper sublittoral, Laminaria saccharina (Linnaeus) Lamouroux in the mid-sublittoral and Laminaria hyperborea (Gunnerus) Foslie in the lower sublittoral (Lüning 1979). A mixed stand of L. digitata and $L$. saccharina is, however, found on the upper sublittoral $(0-1.5-\mathrm{m}$ depth) of the western intertidal flat of the island (Lüning 1985). Moreover, timing of reproduction is different in the three species. L. digitata is fertile during late spring to summer (May-August), $L$. saccharina during autumn to mid winter (SeptemberFebruary) and L. hyperborea during late autumn to winter (November-February). Zoospore sensitivity in terms of recovery of photosynthetic efficiency, DNA damage repair and germination rate of Helgolandic kelp species was found to be related to the depth distribution of the adult sporophytes and to the seasonal reproductive strategy of the species (Roleda et al. 2005a). Spores 
and germlings of kelps are found to remain viable in plankton for extended periods of time (Reed et al. 1992). Exposure to environmental stress factors, e.g. high light, ultraviolet radiation (UVR) and temperature, contribute to pre-settlement mortality whereas surviving spores are capable of dispersal, settlement, attachment and initiation of new recruits across the expanse of the vertical tidal zones. The sensitivity of the young recruits to the same stress factors could contribute to post-settlement mortality, which effectively determines the upper distribution limit of each species. A relation between the effect of UVR on the growth of young sporophytes and the depth distribution of kelps in Helgoland was previously sought but not found (Dring et al. 1996).

With respect to stratospheric ozone depletion and the resulting enhanced UVB radiation (UVBR), several negative effects are reported on the physiology and productivity of marine macrophytes. This includes photoinhibition and eventual photodamage to the photosynthetic apparatus (Hanelt et al. 1997a, b), photochemical degradation of biomolecules inhibiting important metabolic processes (Franklin and Forster 1997), formation of cyclobutane-pyrimidine dimers (CPDs) in the DNA inhibiting genome replication and expression (Wiencke et al. 2000; van de Poll et al. 2001, 2002) and production of reactive oxygen species responsible for oxidative damage within the cell (Aguilera et al. 2002a). Under photoreactivating light, DNA damage in macroalgal spores and young sporophytes is repaired (van de Poll et al. 2002; Roleda et al. 2004a, 2005a), whereas protection by enlargement and increase in number of phlorotannin-containing physodes is observed in zoospores exposed to UVR, enhancing germination capacity (Wiencke et al. 2004). The physiological balance to counteract the negative effects can, however, increase energy demands for protection and repair at the expense of growth.

Species morphology is an important trait in algal ecology. Littler and Littler (1980) defined functionalform groups in marine macroalgae and grouped the genus Laminaria in the thick leathery functional form. However, different thallus thicknesses are observed in different species of the genus, whereby L. hyperborea is considered the thickest leathery species (Johansson and Snoeijs 2002). With respect to photosynthetic efficiency, UVR tolerance is higher in species with increasing thallus thickness (Franklin and Forster 1997). The optical effect of the outer cell layers can influence reflection, attenuation, scattering, absorption or transmittance of UV radiation to the inner cells (Caldwell et al. 1983). Translucence and opacity of the thallus related to pigments and presence of UV-absorbing compounds was also found to affect growth and DNA sensitivity of other young Laminariales sporophytes (Roleda et al. 2005b).

In a previous study on the effect of UVR on young Laminaria sporophytes, unrealistically high doses of different exposure lengths ranging from 0.25 (15 min) to $144 \mathrm{~h}$ (6 days) of UVR were applied. Bleaching and zero growth rates were observed in all species exposed to $72 \mathrm{~h}$ or more of UVR (Dring et al. 1996). After development of the on-line growth measurement system by Lüning $(1992,1994)$ for Laminaria and similar species, short-term (3-6 days) day and night kinetics of growth under L:D photoperiod, continuous light and different light spectra are possible. An improved growth chamber with advance software allowed Roleda et al. (2004b, 2005b) to measure growth in intervals of 10 min over a longer period of time, which will be used in the present study.

Dispersal and potential recruitment of kelp germlings in the eulittoral zone is possible. However, they can be exposed to air and the whole spectrum of solar radiation during low tides, which may contribute to the postrecruitment mortality of the species. We will test the hypothesis that susceptibility of young sporophytes to UVR influences the upper depth distribution limit of the mature sporophytes. The present study will re-examine the effect of UVR on the growth of young Laminaria sporophytes exposed to moderate dose of UVR supplemented in the middle of the light phase. Growth as an integrative parameter of all physiological and biochemical processes will be measured every $10 \mathrm{~min}$ for 18-21 days. This study extends to investigate accumulation of CPDs in the tissue as a measure of DNA damage and repair capacity after repeated exposure to UVR. Thallus thickness and the presence of UV-absorbing compounds in young cultured and wild sporophytes were examined and discussed in relation to the species sensitivity to UVR.

\section{Materials and methods}

\section{Algal material}

Stock gametophyte cultures of L. digitata, L. saccharina and $L$. hyperborea gametophytes, originally established from spores of fertile sporophytes collected around Helgoland, North Sea, were used to obtain young sporophytes. Filaments of male and female gametophytes were fragmented together using mortar and pestle and transferred to culture dishes filled with Provasolienriched seawater (Starr and Zeikus 1993). Cultures were maintained inside a temperature-controlled room at $12 \pm 2{ }^{\circ} \mathrm{C}$ and $10 \mu \mathrm{mol} \mathrm{m}{ }^{-2} \mathrm{~s}^{-1}$ white light at $12: 12 \mathrm{~h}$ light:dark photoperiod. Gametangia were formed and at about 6 weeks, young sporophytes (approximately $3 \mathrm{~mm}$ length) were taken from the bottom of the culture dishes and transferred to aerated 51 culture bottles until sporophyte size was ready for the experiment. To compare morphological differences between cultured and wild specimens, young sporophytes of $L$. digitata were collected by hand in the upper sublittoral $(0.5-1 \mathrm{~m})$ during low tide, while L. saccharina and L. hyperborea were collected by SCUBA diving in the mid (2-4 m) and lower $(5-7 \mathrm{~m})$ sublittoral, respectively, around the island of Helgoland. 
On-line video growth measurement technique

Three growth chambers (ISITEC GmbH, Bremerhaven, Germany) with circulating water system and on-line video measuring technique were operated simultaneously in the experiment as described by Roleda et al. (2004b, $2005 b)$. Each growth chamber contained two basal pieces of thalli (average size $=30 \mathrm{~mm}^{2}, \pm 6 \mathrm{~mm}$ of the blade including the meristem), positioned $20 \mathrm{~mm}$ apart from each other. The video-captured image is analysed by MedeaLAB Count and Classify software (Multimedia and Software $\mathrm{GmbH}$, Erlangen, Germany), which measures growth in terms of increased number of pixel size of the algae. After 3 days of acclimation to 16:8 light-dark photoperiods of white light, UVR was supplemented in the middle of the light phase (0900$1500 \mathrm{~h})$. Two types of glass filters, Schott-GG 400 (Schott, Germany) and Quartz glass slides, were put on the top of the Plexiglas chamber, each covering one of the two algal samples, respectively. This corresponds to two treatments per chamber with photosynthetically active radiation $(\mathrm{PAR}=\mathrm{P})$ and $\mathrm{PAR}+\mathrm{UVA}+\mathrm{UVB}$ (PAB) treatment. The three growth chambers operated simultaneously per species were used as replicates for the $\mathrm{P}$ and PAB treatments.

Light sources in each chamber consisted of two white fluorescent lamps (Philips, TL 8W/965, Holland) and two UV lamps (Q-Panel UVA-340, $40 \mathrm{~W}$, Cleveland, USA). The PAR was measured using a cosine quantum sensor (Type 1925B; LI-COR Biosciences, Bad Homburg, Germany) attached to a LI-COR data logger (LI-1000) and UVR was measured using a scanning UV-VIS spectrometer (M. Kruse, Bremerhaven, Germany) below the glass filters. Weighted irradiance was calculated using action spectra for wellknown biological responses: DNA damage for $E s c$ herichia coli (280-320 nm, Setlow 1974) and the generalized plant damage (280-312 nm) described by Caldwell (1971). Both unweighted and weighted irradiances for each treatment are compiled in Table 1. Growth was continuously measured every $10 \mathrm{~min}$ for 18-21 days. Seawater was changed weekly to ensure enough nutrient supply within the medium. At the end of each growth experiment, algal thalli were transferred to $2 \mathrm{ml}$ Eppendorf tubes and frozen at $-80^{\circ} \mathrm{C}$ for further chemical analyses.
Growth rate was computed by plotting all data points (of the entire experimental period) of each replicate per treatment. They were individually fitted to an exponential equation $N_{t}=N_{0} \mathrm{e}^{r t}$, where $N_{t}$ is growth at time $t, N_{0}$ is initial size and $r$ is the intrinsic rate of increase (Roleda et al. 2004b, 2005b). To determine the circadian growth rates of the sporophytes exposed to $\mathrm{P}$ and $\mathrm{PAB}$ treatments, 3-day averages (percent per hour) were computed during the start of the light phase without UV (0500$0900 \mathrm{~h}$ ), in the middle of the light phase with UV supplement (0900-1500 h), at the end of the light phase without UV (1500-2100 h) and during the dark phase (2100-0500 h).

\section{Thallus morphology and optics}

To determine thallus thickness, wet weight:surface area (mg: $\mathrm{mm}^{2}$ ) ratio was measured as described by Roleda et al. (2004a, 2005b). Surface area of sporophytes taken directly from the unialgal cultures was measured using a scanner and WinFolia 5.0 image analysis software (Regent Instrument, Quebec City, Canada). The corresponding wet weight of the blotted tissue was weighed using Sartorius (CP225D, Germany) weighing scale $(n=10)$. To determine the optical property of cultured and wild specimens, young sporophytes were inserted into seawater-filled quartz cuvettes and scanned with seawater as reference in the 250-700 $\mathrm{nm}$ waveband using Shimadzu photometer (UV 2401PC, Japan) equipped with an integrating sphere.

\section{Pigment extraction and characterization}

Frozen samples were treated with $100 \mu \mathrm{l}$ of $100 \% \mathrm{~N}-\mathrm{N}$ dimethylformamide and stored in darkness for approximately $16 \mathrm{~h}$. Subsequent analyses were performed using HPLC as described by Bischof et al. (2002).

\section{DNA extraction and quantification}

Thalli were homogenized in liquid nitrogen and DNA was isolated following the CTAB extraction procedure described by van de Poll et al. (2001) and modified by

Table 1 Unweighted and weighted irradiance applied in the growth chambers

\begin{tabular}{lllll}
\hline & \multicolumn{2}{l}{ Irradiance $\left(\mathrm{W} \mathrm{m}^{-2}\right)$} & & \\
\cline { 2 - 5 } & Unweighted & & Weighted \\
\cline { 2 - 5 } & $\begin{array}{l}\text { GG 400 } \\
\text { (PAR alone) }\end{array}$ & $\begin{array}{l}\text { Quartz } \\
\text { (PAR + UVA + UVB) }\end{array}$ & $\begin{array}{l}\text { DNA damage } \\
\text { (Setlow 1974) }\end{array}$ & $\begin{array}{l}\text { Generalized plant damage } \\
\text { (Caldwell 1971) }\end{array}$ \\
\hline PAR (400-700 nm) & 3.60 & 4.00 & 0 & 0 \\
UVA (320-400 nm) & 0.02 & 4.92 & 0 & 0 \\
UVB (280-320 nm) & 0.00 & 0.41 & $9.76 \times 10^{-3}$ & $3.16 \times 10^{-2}$ \\
Total irradiance & 3.62 & 9.33 & $9.76 \times 10^{-3}$ & $3.16 \times 10^{-2}$ \\
\hline
\end{tabular}


Roleda et al. (2004a). After DNA extraction, the pellet was dissolved in $0.2 \mathrm{ml}$ TE buffer $(10 \mathrm{mM}$ Tris, $1 \mathrm{mM}$ EDTA, pH 8.0), treated with RNAase $\left(5 \mu 10 \mathrm{mg} \mathrm{ml}^{-1}\right.$, $30 \mathrm{~min}, 37^{\circ} \mathrm{C}$; Sigma, MO, USA) and stored at $-20^{\circ} \mathrm{C}$. The DNA concentration was quantified fluorometrically using PicoGreen assay (Molecular Probes, Eugene, OR, USA) and a Cary Eclipse Fluorescence Spectrophotometer (Variance Scientific Instrument, CA, USA). A dilution series with a known amount of DNA (Serva, Heidelberg, Germany) was included for calibration purposes.

\section{Assay for CPDs detection}

The immunoassay for CPDs was modified after Vink et al. (1994) and van de Poll et al. (2001). Heat-denatured samples containing 50 ng DNA were transferred to a nitrocellulose membrane (Protran BA 79, pore size $0.1 \mu \mathrm{m}$, Schleicher and Schuell, Keene, NH, USA) with a Minifold I SRC96 dot blot apparatus (Schleicher and Schuell). After a two-step antibody assay, the membrane was treated with ECL Western blotting detection reagent (Amersham Buckinghamshire, UK) and sealed in a transparent vinyl plastic folder (Leitz, Stuttgart, Germany). This was subsequently exposed to photosensitive ECL films (Amersham), with different exposure times. The films were developed using an X-ray film developer. Developed films were scanned using a Biorad imaging densitometer (Model GS-700, Bio-Rad Laboratories, Hercules, CA, USA) and gray scale values were quantified using Multi-Analyst (Macintosh Software for Bio-Rad's Image Analysis Systems). A calibration series of UV-irradiated calf thymus DNA (Serva) supplemented with unexposed DNA was included, giving $1 \mu \mathrm{g} \mathrm{ml}^{-1}$ DNA for each calibration point. The UV-irradiated DNA (45 min exposure to two TL $20 \mathrm{~W} /$ 12 lamps, Philips, Eindhoven, Netherlands) was previously calibrated against UV-irradiated Hela DNA with known amounts of CPDs (kindly provided by A. Vink). The CPDs were quantified by comparing the gray scales within the linear range of the film.

\section{Data analysis}

The statistically significant differences in growth rate (percent per day), CPDs accumulation and thallus thickness (wet weight:surface area ratio; $\mathrm{mg}: \mathrm{mm}^{2}$ ) between species were tested using ANOVA $(P<0.05)$, and the difference between treatments (P versus $\mathrm{PAB})$ was tested by $t$-test $(P<0.05)$ using SPSS software (SPSS, Chicago, IL, USA). The general trends in the circadian growth pattern (percent per hour) were described.

\section{Results}

Higher intrinsic rates of increase in surface area were observed in sporophytes of all three species exposed to $\mathrm{P}$ alone compared to sporophytes exposed to PAB (Fig. 1). Significant difference in growth rates was observed between species (percent per day; insets Fig. 1a, b) exposed to $\mathrm{P}$ and $\mathrm{PAB}$ (ANOVA, $P<0.01$ ). The corresponding Duncan multiple range test (DMRT, $P=0.05)$ showed significantly lower growth rates in $L$. hyperborea sporophytes exposed to $\mathrm{P}$ and $\mathrm{PAB}$ compared to the other two kelp species. However, the difference in growth rates between $L$. digitata and $L$. saccharina is not significant in both treatments. Relative growth rates of sporophytes exposed to $\mathrm{PAB}$, expressed as percent of $\mathrm{P}$, showed significant effect of UVR (ANOVA, $P<0.05)$. The DMRT $(P=0.05)$, however, showed that $L$. digitata is not significantly different from L. saccharina and L. saccharina is not significantly different from L. hyperborea (Fig. 2).

The circadian growth pattern in sporophytes exposed to $\mathrm{P}$ alone generally showed an increasing growth from the onset of light $(0500-0900 \mathrm{~h})$ to a peak at the middle $(0900-1500 \mathrm{~h})$ or at the end of the light phase $(1500$ $2100 \mathrm{~h}$ ) and a minimum "low" growth in the dark phase (2100-0500 h) (Fig. 3a-c). Among sporophytes exposed to the full light spectrum (PAB), circadian growth pattern was observed to be species specific. After UV exposure, a relative decrease in the growth rate of $L$. digitata was observed at the end of the light phase (1500-2100), but this was compensated with a higher growth rate in the dark phase (2100-0500) (Fig. 3a). A similar pattern was observed in L. hyperborea (Fig. 3c) but lower growth rate was observed during the dark phase compared to L. digitata. In L. saccharina, growth rates generally increased at the end of the light phase (1500-2100) after UV exposure, while growth rates during the dark phase varied over the observation period (Fig. 3b).

Growth rates of young sporophytes were initially able to acclimate to UVR in the course of several days (4-12 days) of repeated exposure (Fig. 4). However, at longer exposure periods (13-21 days), growth rates were eventually observed to decline through time. Average growth rates during UVR exposure (0900-1500 h) over a period of 18-21 days showed significant differences between species (ANOVA, $P<0.05$ ). Duncan's multiple range test showed no significant variation between $L$. digitata and L. saccharina except growth during the 3rd and 18th day (DMRT, $P=0.05$ ), while significantly lower growth rates were observed in $L$. hyperborea during the 9 th, 12 th and 18 th day (DMRT, $P=0.05$ ).

Higher wet weight:surface area ratio corresponds to thicker thallus as observed visually and tactually among different species of cultured sporophytes. Analysis of variance (ANOVA, $P<0.001$ ) and Duncan Multiple Range Test (DMRT, $P=0.05$ ) showed significant differences between species with $L$. saccharina having the thinnest and L. hyperborea the thickest thalli (Fig. 5). DNA damage measured as number of CPDs after 1821 days of daily $6 \mathrm{~h}$ exposure to UVR showed inverse relationship with thallus thickness (Fig. 5). Significantly higher remaining CPDs $(P<0.01)$ was measured in the 
Fig. 1 Growth, in terms of surface area increase, in young sporophytes exposed to a photosynthetically active radiation $(\mathrm{PAR}=\mathrm{P})$ and $\mathbf{b}$ $\mathrm{PAR}+\mathrm{UVA}+\mathrm{UVB}(=\mathrm{PAB})$. PFD was $\pm 18 \mu \mathrm{mol} \mathrm{m}{ }^{-2} \mathrm{~s}^{-1}$. Data points (irregular coloured points) are fitted using the exponential growth equation $N_{t}=N_{0} \mathrm{e}^{r t}$ (solid curves), where $N_{t}$ is growth at time $t$ and $N_{0}$ is initial size. Values are means \pm SD (light gray one sided vertical lines, $n=3$ ). Inset is the corresponding daily growth rates (percent per day) for the entire experimental period. ANOVA showed significant difference between species $(P<0.05)$. Letters on graph show result of DMRT $(P=0.05)$; different letters refer to significant differences between means
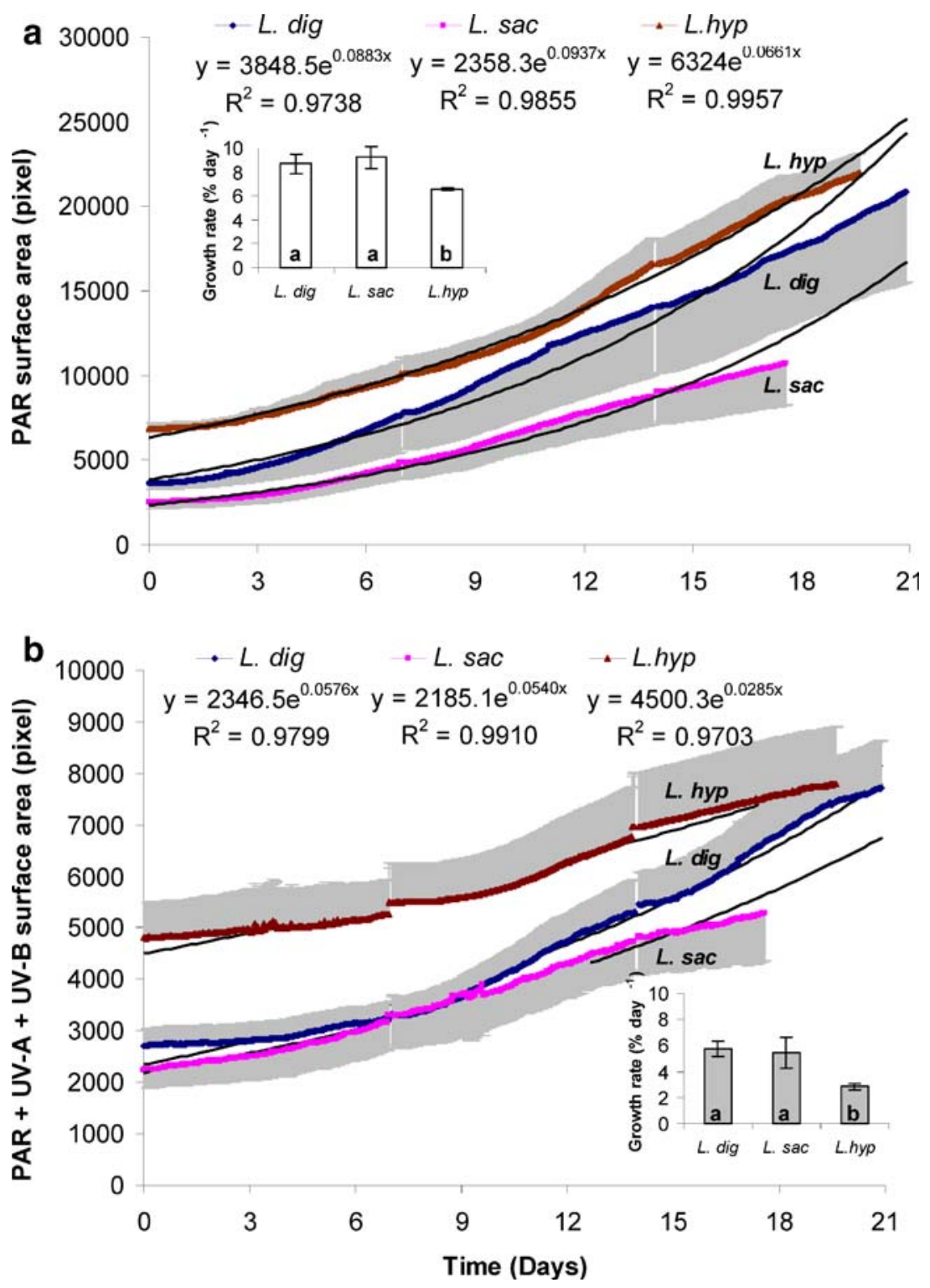

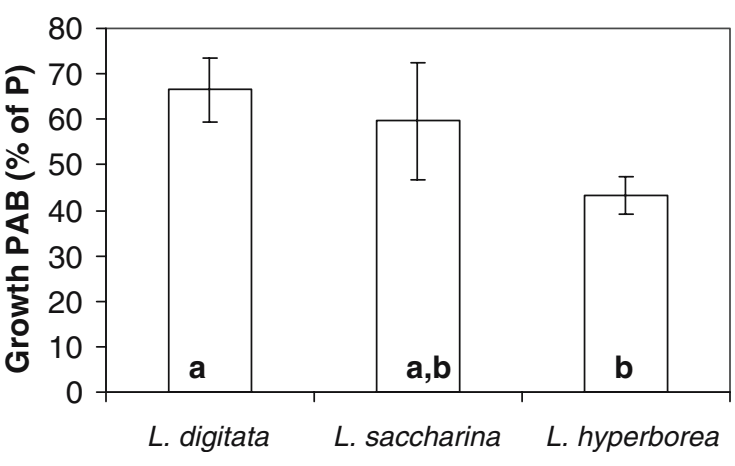

Fig. 2 Ultraviolet radiation effect on the growth rates of young Laminaria sporophytes. Growth rates of sporophytes exposed to $\mathrm{PAR}+\mathrm{UVA}+\mathrm{UVB}$ (PAB) were expressed as percent of the growth rates of sporophytes exposed to PAR alone (percent P). ANOVA showed significant difference between species $(P<0.05)$. Letters on graph show result of DMRT $(P=0.05)$; different letters refer to significant differences between means tissue of the thinner L. saccharina compared to the two other species. No significant differences in the remaining CPDs were observed between the thicker thalli of $L$. digitata and L. hyperborea. No significant difference was observed in the pigment concentration between $L$. digitata and L. hyperborea sporophytes exposed to $\mathrm{P}$ and PAB (Fig. 6). Due to sample limitation, no replicates were measured in L. saccharina.

Different thallus morphology and growth forms were observed between young cultured and wild sporophytes (insets Fig. 7a, b). Wild sporophytes were thicker than cultured sporophytes, while both isolates are leathery in texture. L. saccharina was, however, optically lighter than $L$. digitata and L. hyperborea. Corresponding spectral analysis of wild young sporophytes showed higher absorbance peak at $678 \mathrm{~nm}$ representing chlorophyll a peak and peaks between $425-450 \mathrm{~nm}$ representing additionally higher carotenoid content in wild $L$. 
Fig. 3 Average circadian growth patterns of young a $L$. digitata b $L$. saccharina $\mathbf{c} L$. hyperborea sporophytes $(n=3)$ exposed to PAR (P) and to the full light spectrum (PAB) at the start of the light phase to PAR without UV (0500-0900 h); in the middle of the light phase with UV supplement (0900$1500 \mathrm{~h}$; red-colour filled symbols); at the end of the light phase again without UV (1500 $2100 \mathrm{~h}$ ); and during the dark phase $(2100-0500 \mathrm{~h}$; greycolour filled symbols). Each point represents the mean of 3 days \pm SD. * refers to significant difference between means ( $t$-test, $P<0.05$ )
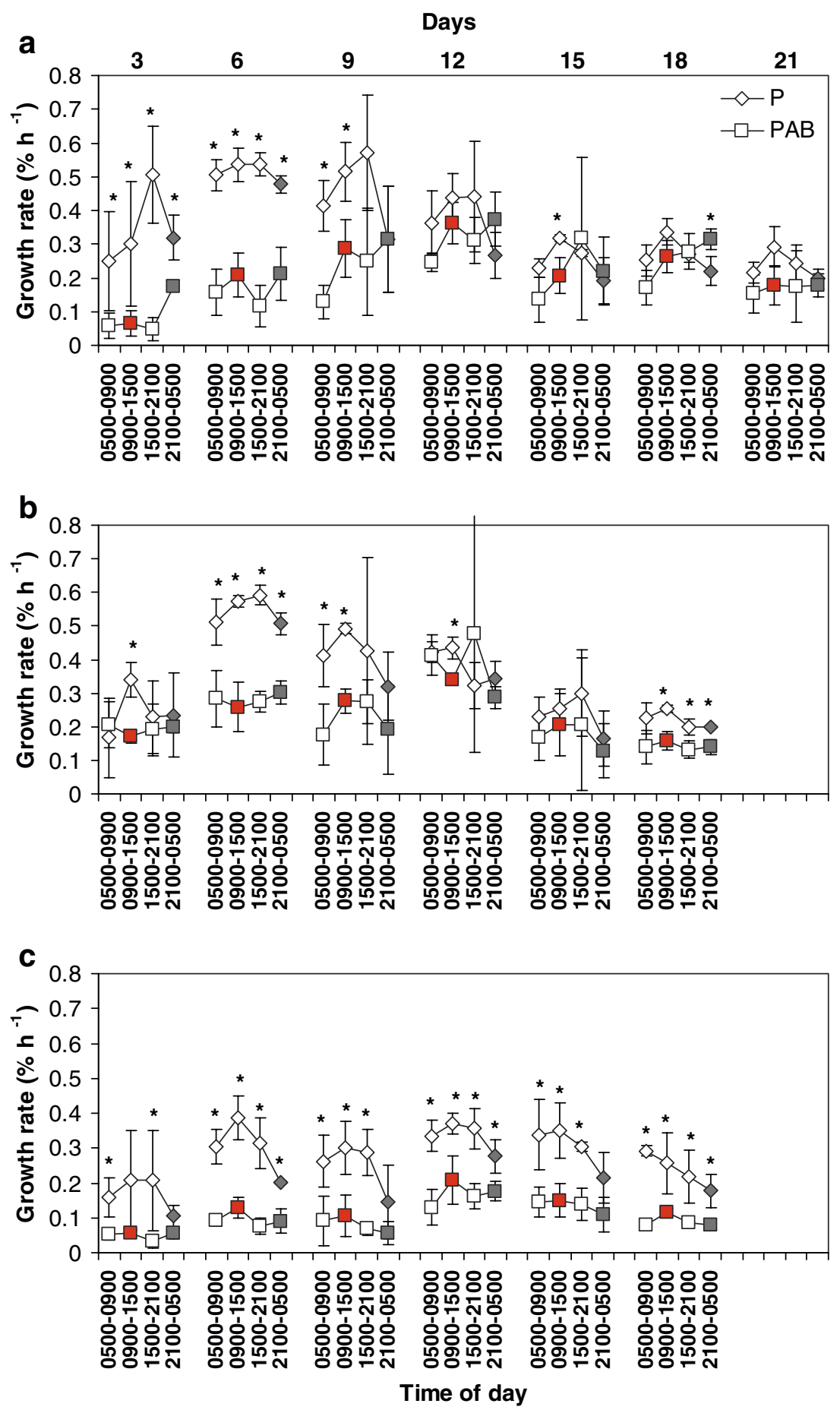

digitata and L. hyperborea. Strong absorbance below $280 \mathrm{~nm}$ was measured in the thalli of wild sporophytes, characteristic of the UV-absorbing compound phlorotannin.

\section{Discussion}

The UVR sensitivity of growth as an integrative parameter of all physiological processes is related to the upper distribution limit of the three kelp species in Helgoland. Tissue DNA damage is, however, dependent on thallus thickness, optics and absorption spectra characteristics of the pigments and UV-absorbing compounds. Energy demands for repair and protection may divert photosynthate at the expense of growth.

Growth as an integrative parameter of all cellular processes is better than photosynthetic performance to study long-term effects of UV exposure in macroalgae (Roleda et al. 2004b). A simple growth model: $G=P-R-L$, 


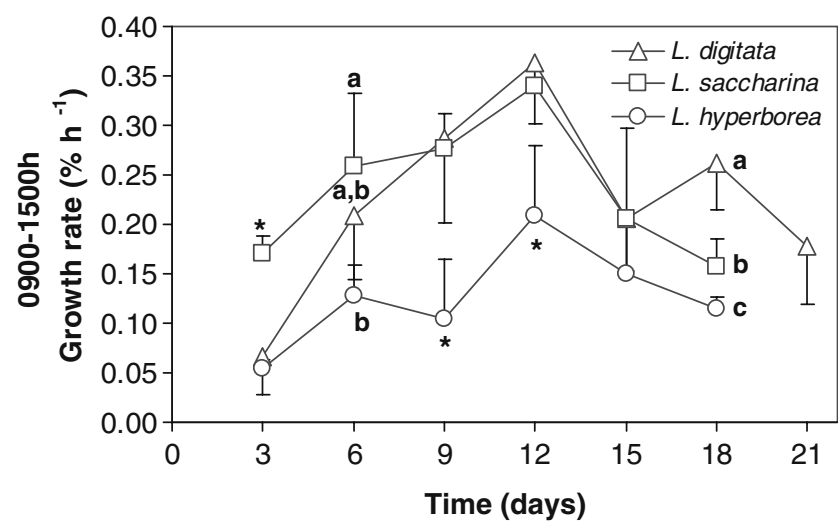

Fig. 4 Average growth rates over a period of 21 days in young sporophytes of the three Laminaria species $(n=3)$ during UVR exposure (0900-1500 h). ANOVA showed significant difference between species $(P<0.05)$. Letters on graph show result of DMRT $(P=0.05)$; different letters refer to significant differences between means. * suggests that one species is significantly different from the other two species while the other two species are not significantly different from each other

follows a growth-differentiation balance, where growth increment over time $(G)$ is a function of the rate of biomass production through gross photosynthesis $(P)$ and loss due to respiration $(R)$ and tissue lost or decay (L) (Carr et al. 1997). Under high-light intensity and UVR, photoinhibition of photosynthesis already decreases potential carbon acquisition $(P)$ into plant dry matter $(G)$ (Long et al. 1994). Dark respiration $(R)$ represents the energy used to synthesize new biomass (growth respiration) and that used to maintain metabolic activity (maintenance respiration). Exposure to UVR causes cellular, enzymatic and molecular damage, which could further increase loss due to respiration $(R)$ by diverting more photosynthate for repair and defense

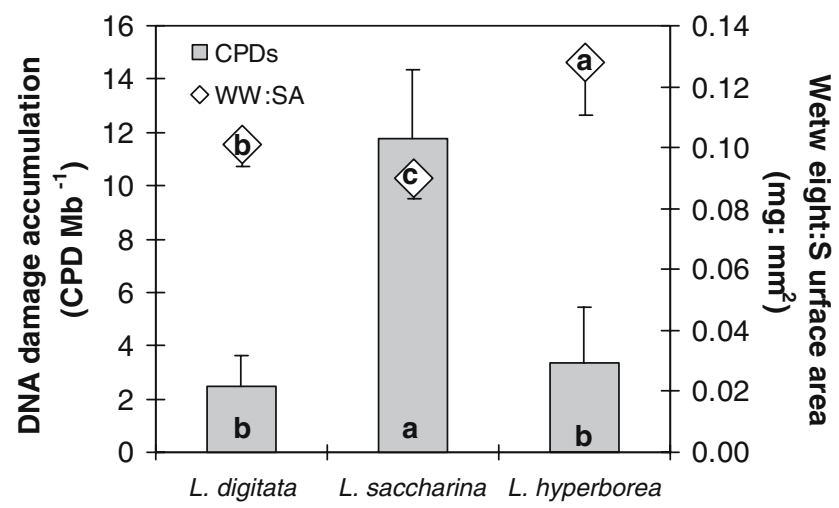

Fig. 5 Relationship between average thallus thickness and remaining tissue DNA damage after 18-21 days of repeated daily $6 \mathrm{~h}$ UVR exposure and $18 \mathrm{~h}$ recovery (6:8:4 h light:dark:light cycle) in the three Laminaria species. Vertical bars are standard deviations $(n=3)$. ANOVA showed significant difference between species $(P<0.05)$. Letters on graph show result of DMRT $(P=0.05)$; different letters refer to significant differences between means

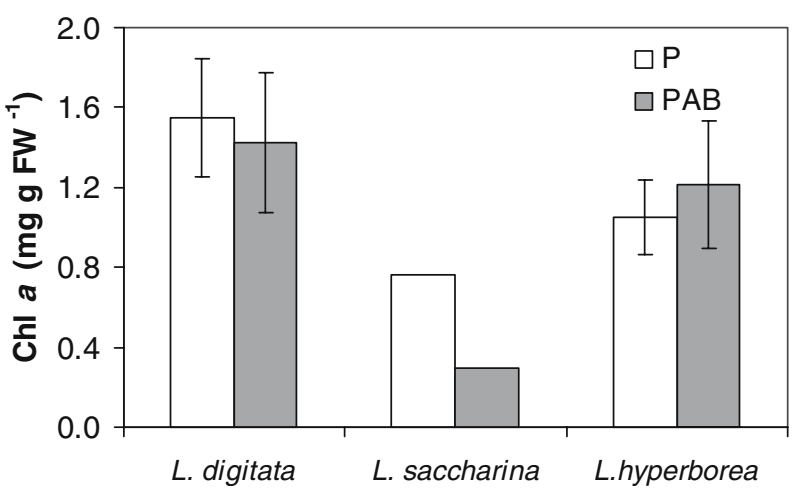

Fig. 6 Chlorophyll a content in young sporophytes exposed to different irradiances $(\mathrm{PAR}=\mathrm{P} ; \mathrm{PAR}+\mathrm{UVA}+\mathrm{UVB}=\mathrm{PAB})$. Vertical bars are standard deviations $(n=3)$. Value of $L$. saccharina represents one replicate only

(i.e. production of secondary metabolites) thereby inhibiting growth.

Saturation of growth in young sporophytes of $L$. digitata, L. saccharina and L. hyperborea was previously reported at $20-30 \mu \mathrm{mol}$ photon $\mathrm{m}^{-2} \mathrm{~s}^{-1}$ of continuous photon irradiance, whereas $1-2 \mu \mathrm{mol}$ photon $\mathrm{m}^{-2} \mathrm{~s}^{-1}$ was able to sustain growth in culture (Han and Kain 1996). At $18 \mu \mathrm{mol}$ photon $\mathrm{m}^{-2} \mathrm{~s}^{-1}$ in this study, maximum growth rate in L. digitata $(1500-2100 \mathrm{~h}$, $0.57 \pm 0.17 \% \mathrm{~h}^{-1}$ ) is comparable to the previous online growth measurements of Lüning (1994) on the same species from Helgoland reported at $0.5 \% \mathrm{~h}^{-1}$. Growth rate in L. saccharina $\left(1500-2100 \mathrm{~h}, 0.59 \pm 0.03 \% \mathrm{~h}^{-1}\right)$ is, however, lower compared to the previous study reported at $0.7 \% \mathrm{~h}^{-1}$ (Lüning 1992). Comparison with other Laminariales showed higher growth rates among Laminaria species than in Saccorhiza dermatodea $(0.42 \pm$ $\left.0.12 \% \mathrm{~h}^{-1}\right)$ and Alaria esculenta $\left(0.31 \pm 0.02 \% \mathrm{~h}^{-1}\right.$ measured during the dark phase) (Roleda et al. 2005b). The pioneering work of Lüning (1992) on on-line growth measurements within 3 days showed an increasing growth rate throughout the light phase and a subsequent continuous decrease in growth at the onset of darkness. However, the present on-line growth measurement which lasted for 18 days recorded a general growth trend showing an initial low growth during early morning, a mid morning or late afternoon peak and minimum growth during the dark phase. The circadian rhythm in growth has been reported to be associated with the circadian rhythm in gene expression, cell division and photosynthesis (Lüning 2001; Suzuki and Johnson 2001; Jacobsen et al. 2003). The decrease in growth rate through time observed in this study was also evident in the subsequent study of Lüning (1994), which recorded decreasing growth in the course of measurement over 6 days. In situ growth measurements on the three Laminaria species in Helgoland were also observed to decrease through time (Lüning 1979). The decrease in the intrinsic rate of increase in growth through time is attributed to the increase in doubling time for the cell mass (Brinkhuis 1985). 
Fig. 7 Tissue absorbance spectrum of a cultured and $\mathbf{b}$ wild young Laminaria spp. sporophytes. The insets show photographs of the typical morphology of thalli among the three species of kelps used for the experiments
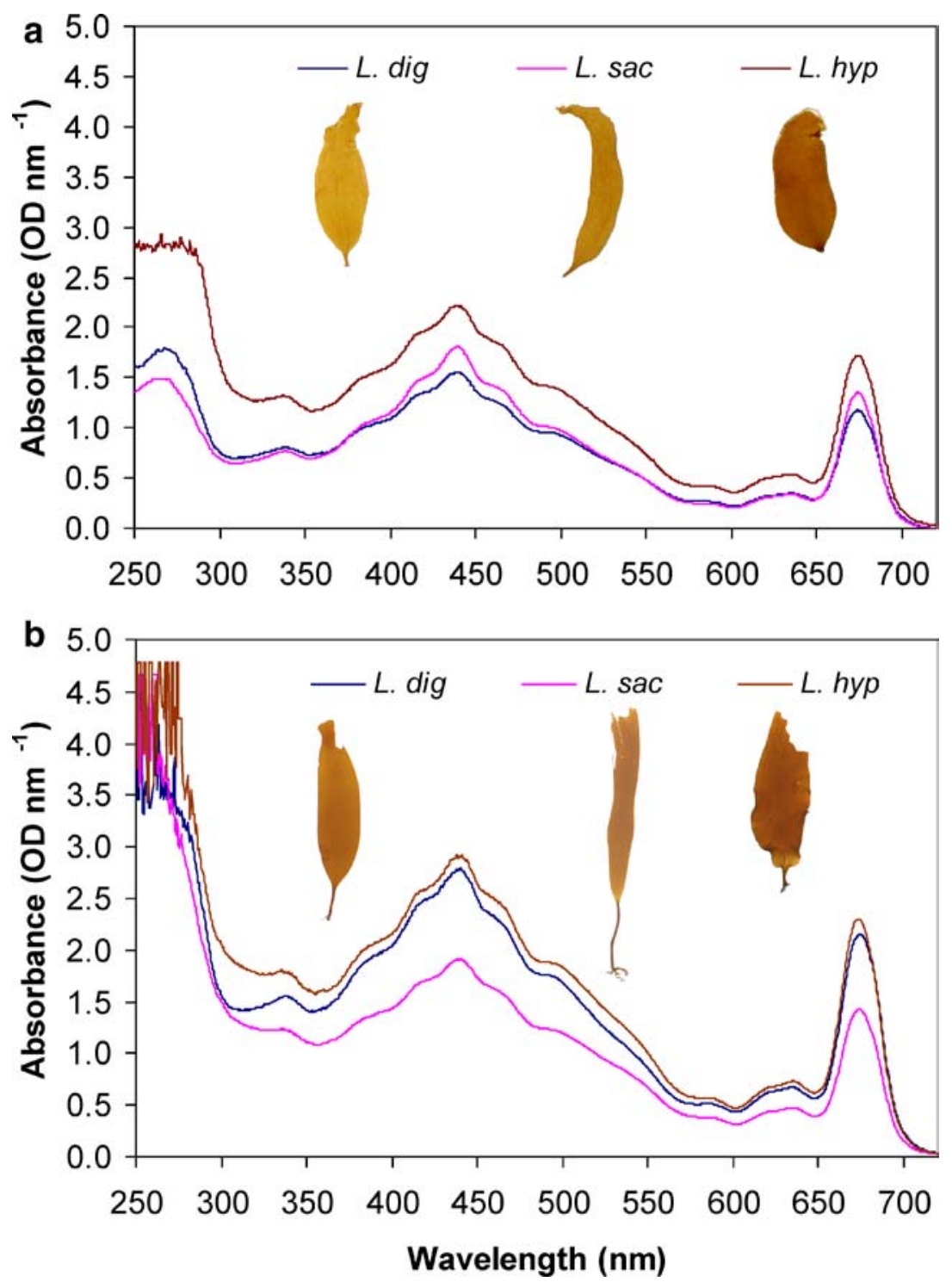

A circadian growth pattern of sporophytes exposed to UV-radiation was first reported by Roleda et al. (2005b) where dark pigmented young A. esculenta sporophytes were able to acclimate to UVR while translucent young $S$. dermatodea did not. The general growth pattern of $A$. esculenta and $S$. dermatodea exhibits a drop in growth rate during UVR exposure (0900-1500) relative to growth during early morning (0500-0900) and late afternoon (1500-2100) without UVR and at night (2100-0500). The circadian growth strategies of the three Laminaria species are different compared to that of $A$. esculenta and $S$. dermatodea. In $L$. digitata, the drop in growth during UVR exposure was observed only during the first 3 days. Growth was eventually able to acclimate to UVR, where growth rates at this time (0900-1500) were higher compared to the early morning growth. The decline in growth in the afternoon when UV lamps were turned off was compensated with a corresponding higher growth rate at night. This follows the general diurnal pattern observed among sporophytes exposed to PAR alone. However, at night, higher growth rates were observed relative to growth during the day in sporophytes exposed to UVR. In L. saccharina, although growth was also able to acclimate up to 12 days repeated UV exposure, the circadian growth patterns between P- and PAB-exposed sporophytes were relatively similar and follow the typical low early morning growth, midday peak, afternoon decline and low evening growth rhythm. In L. hyperborea, moderate growth rates were observed throughout the daily light cycle of PAB-exposed sporophytes. They were able to cope up with the daily UV dose throughout the experiment when growth during UVR exposure (0900-1500) did not drop relative to the early morning growth (0500-0900) without UVR. However, growth decreased after UVR exposure, similar to the pattern observed in L . digitata, but distinct growth compensation at night was observed only until the sixth day. 
Based on the remaining tissue DNA damage, it is inferred that sensitivity of young sporophytes is not related to the depth distribution of the adult sporophytes but on the thallus thickness of the species. L. saccharina, which can occur in the upper sublittoral intermixed with L. digitata stand and in the mid sublittoral (Lüning $1979,1985)$, is more sensitive to UVBR-induced DNA damage. This is attributed to its thinner and relatively translucent thalli. Although L. saccharina had the highest remaining tissue CPDs $\left(11.7 \pm 2.6 \mathrm{CPD} \mathrm{\textrm {mb } ^ { - 1 } )}\right.$ after 18 days of repeated daily UVB dose of $8.6 \times 10^{3} \mathrm{~J} \mathrm{~m}^{-2}$, an effective DNA damage repair mechanism is indicated in this species. After daily $6 \mathrm{~h} \mathrm{UVR}$ exposure, the sporophytes were able to recover for $18 \mathrm{~h}$ under the daily light:dark cycle. Previously, induction of CPDs in Arctic L. saccharina exposed to lower UVB dose of $6.2 \times 10^{3} \mathrm{~J} \mathrm{~m}^{-2}$ resulted in a high accumulation of $88 \mathrm{CPD} \mathrm{mb} \mathrm{m}^{-1}$, which was effectively repaired after $5 \mathrm{~h}$ exposure to photo-reactivating light at the rate of 0.49 CPD $\mathrm{mb}^{-1} \mathrm{~h}^{-1}$ (van de Poll et al. 2002). Efficient DNA damage repair was also observed in 8 hours UVRexposed zoospores after $48 \mathrm{~h}$ recovery in low-white light whereby remaining DNA damage was undetectable in $L$. digitata, $3.8 \pm 1$ and $7.0 \pm 4 \mathrm{CPD} \mathrm{mb}^{-1}$ in L. saccharina and $L$. hyperborea, respectively (Roleda et al. 2005a).

Laminaria digitata, which occurs in the upper sublittoral and L. hyperborea, which occurs deepest in the field reduce effective UV fluence from reaching the physiological target by means of thick thalli. It shows that thicker thalli can provide extra protective tissue against UVR (Johansson and Snoeijs 2002), where outer cell layers shade inner cells and provide longer pathlength for UVR absorption (Franklin and Forster 1997) making it less sensitive to UVB radiation-induced DNA damage. The epidermis itself already serves as a filter of UVB radiation and the optical property of the thallus can further influence reflection, attenuation, scattering, absorption or transmittance of UV radiation (Caldwell et al. 1983). The significance of thallus optics was previously reported by Roleda et al. (2005b). The thick but translucent thallus of $S$. dermatodea accumulated higher CPD content of $65 \pm 9 \mathrm{CPD} \mathrm{mb}^{-1}$ compared to the thin but opaque $A$. esculenta $\left(8 \pm 3 \mathrm{CPD} \mathrm{mb}^{-1}\right)$ after exposure to the same experimental treatment (Roleda et al. 2005b). Thus, remaining tissue DNA damage in young sporophytes alone cannot explain the survival success between these species.

Zoospores of the same species are relatively more sensitive to DNA damage and their sensitivity is related to the vertical distribution pattern of the large sporophytes (Roleda et al. 2005a). In young sporophytes, DNA damage measured in L. digitata $(2.5 \pm 1$ CPD $\left.\mathrm{mb}^{-1}\right)$, L. saccharina $\left(11.7 \pm 3 \mathrm{CPD} \mathrm{mb}^{-1}\right)$ and $L$. hyperborea $\left(3.4 \pm 2 \mathrm{CPD} \mathrm{mb}^{-1}\right)$ after $18-21$ days of repeated $6 \mathrm{~h}$ daily UVR exposure is less than the number of CPDs observed in zoospores exposed to $8 \mathrm{~h}$ UVR, accumulating $18.6 \pm 4,30.8 \pm 8$ and $49.8 \pm 6 \mathrm{CPD} \mathrm{mb}^{-1}$, respectively. Ontogenic differences in DNA damage accumulation was previously reported in Mastocarpus stellatus Stackhouse (Guiry) and Chondrus crispus Stackhouse, where carpospores of the two species were observed to be more sensitive compared to the foliose gametophytic life stages (Roleda et al. 2004a). Lower DNA damage and effective DNA damage repair mechanism in carpospores of $M$. stellatus enhanced its recruitment success to the upper eulittoral zone. In comparison across the latitudinal gradient, Arctic Laminaria populations were observed to be more sensitive to DNA damage compared to their temperate counterparts of the same species. Under the same light treatment, significantly higher DNA damage was observed in Arctic L. digitata $\left(23.9 \pm 7.9 \mathrm{CPD} \mathrm{mb}^{-1}\right)$, higher but insignificantly different between $L$. saccharina (Spitsbergen: $12.5 \pm 0.9$; Helgoland: $11.7 \pm 2.6 \mathrm{CPD}$ $\mathrm{mb}^{-1}$ ) populations. Comparison between the deep and thick kelp species L. hyperborea $\left(3.4 \pm 2.1 \mathrm{CPD} \mathrm{mb}^{-1}\right)$

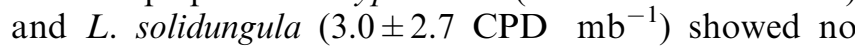
significant difference in DNA damage accumulation (Roleda et al. 2006).

Under moderate fluence of UVR, the insignificant variation in chlorophyll a concentration in sporophytes exposed to $\mathrm{PAB}$ and to $\mathrm{P}$ treatments indicates that algae are able to synthesize new pigments in replacement of degraded chlorophylls after $6 \mathrm{~h}$ daily UVR exposure and acclimate to repeated moderate daily fluence of UVR. Acclimation of chlorophyll a concentration was also observed in the red macroalgae Palmaria decipiens (Reinsch) Ricker exposed to 12-16 h UVR (Poppe et al. 2002). In situ seasonal variation in pigment concentration of Arctic L. saccharina collected before, during and after ice break-up showed decreasing chlorophyll a concentration coinciding with increasing underwater radiation. Chlorophyll a concentration did not increase when melting snow contributed to water turbidity and reduction in underwater radiation (Aguilera et al. 2002b), suggesting irreparable degradation of pigments after exposure to high-light intensity.

Absorption profile and peaks in the Soret region $(400-540 \mathrm{~nm})$ are characteristic of carotenoids in the antenna complexes of higher plants (Pascal et al. 1999; Croce et al. 2000). Carotenoids are involved in several aspects of photosynthesis such as light absorption and energy transfer to the reaction centre complex and protection of the photosynthetic apparatus from damage by strong illumination. The higher absorption in this region among wild sporophytes of Laminariales could imply some photoprotection role of carotenoids.

Strong absorption of sporophyte thallus in the UV region of the spectrum is characteristic of phlorotannin. Isolated phlorotannins from Fucus gardneri Silva absorb strongly in the UV region with peak at $265 \mathrm{~nm}$ (Henry and van Alstyne 2004). In terrestrial plants, the pronounced wavelength selectivity of absorption in leaf epidermis is often attributed to flavonoids and other related UV-absorbing compounds (Robberecht and Caldwell 1978). Phenolic compounds generally have substantial UV absorbance and very little absorption in the visible waveband (Caldwell et al. 1983). Distribution 
of phlorotannins is observed in the epidermis and cell walls of brown algae (Schoenwaelder and Clayton 1999; Lüder and Clayton 2004). UVR can therefore be attenuated by cellular UV-absorbing compounds and cell walls of the epidermal tissue, effectively reducing UV fluence from reaching physiological targets.

Several functions of phlorotannins have been reported in brown algae such as herbivore deterrents, digestion inhibitors, antibacterial agents and UV screens (Schoenwaelder 2002). Production of this compound involves a substantial cost in terms of individual growth (Pavia et al. 1999). However, synthesis of moderate levels of phlorotannins and growth could be maintained simultaneously (Steinberg 1995). Substantial UV absorbance characteristics of phlorotannin in young sporophytes grown in culture as well as in wild specimens supports the hypothesis of Arnold (2003) that synthesis and production of this compound is not strictly inducible as a secondary metabolite but also serves some primary and secondary roles in reproduction, fertilization, spore attachment and cell wall construction. Its synthesis could also be in response to specific environmental cues or stress factors and is allocated for different functions in different kelp species. The physiological cost of producing a higher amount of UV-absorbing compounds is, however, reflected in the lower growth rates of L. hyperborea relative to L. digitata and L. saccharina, which exhibit relatively lower absorption in the UV waveband.

Effective DNA repair mechanism in the zoospores of L. digitata (Roleda et al. 2005a) and in young sporophytes (this study) effectively enhanced recruitment success of this species to the upper sublittoral. The upper distribution limit of $L$. saccharina to the upper sublittoral could be attributed to the timing of its reproductive season in autumn. Zoospore release, fertilization and establishment of new recruits and growth under the canopy of $L$. digitata during low UVR environment of the season contributed to this success. Relative growth tolerance of young L. saccharina sporophytes to UVR extended its upper distribution limit to the upper sublittoral inter-mixed with $L$. digitata stands in some areas of the island. Sensitivity of L. hyperborea zoospores to UVR have been reported such that timing of its reproduction during winter is thought to be an adaptive strategy to prevent reproductive failure (Roleda et al. 2005a). In this study, a trade-off between the physiological cost of repair/defense and growth was observed in L. hyperborea, whilst growth inhibition of young sporophytes under UVR further established the relative sensitivity of this species where successful recruitment is confined within the lower sublittoral of the island.

Acknowledgements MY Roleda is supported by a scholarship from the German Academic Exchange Service (DAAD). We thank the divers of Biologische Anstalt Helgoland for collecting field materials and C. Daniel for pigment analysis. This is publication awi-n 15416 of the Alfred Wegener Institute for Polar and Marine Research. The experiments performed comply with the current laws of Germany.

\section{References}

Aguilera J, Dummermuth A, Karsten U, Schriek R, Wiencke C (2002a) Enzymatic defenses against photooxidative stress induced by ultraviolet radiation in Arctic marine macroalgae. Polar Biol 25:432-441

Aguilera J, Bischof K, Karsten U, Hanelt D, Wiencke C (2002b) Seasonal variation in ecophysiological patterns in macroalgae from an Arctic fjord. II. Pigment accumulation and biochemical defence systems against high light stress. Mar Biol 140:10871095

Arnold TM (2003) To grow and defend: lack of tradeoffs for brown algal phlorotannins. Oikos 100:406-408

Bischof K, Kräbs G, Wiencke C, Hanelt D (2002) Solar ultraviolet radiation affects the activity of ribulose-1,5-biphosphate carboxylase-oxygenase and the composition of photosynthetic and xanthophyll cycle pigments in the intertidal green alga Ulva lactuca L. Planta 215:502-509

Brinkhuis BH (1985) Growth pattern and rates. In: Littler MM, Littler DS (eds) Handbook of phycological methods: ecological field methods: macroalgae. Cambridge University Press, Cambridge, UK, pp 461-477

Carr GM, Duthie HC, Taylor WD (1997) Models of aquatic plant productivity: a review of the factors that influence growth. Aquat Bot 59:195-215

Caldwell MM (1971) Solar ultraviolet radiation and the growth and development of higher plants. In: Giese AC (eds) Photophysiology. Academic Press, New York, pp 131-177

Caldwell MM, Robberecht R, Flint SD (1983) Internal filters: prospects for UV-acclimation in higher plants. Physiol Plant 58:445-450

Croce R, Cinque G, Holzwarth AR, Bassi R (2000) The Soret absorption properties of carotenoids and chlorophylls in antenna complexes of higher plants. Photosynth Res 64:221-231

Dring MJ, Makarov V, Schoschina E, Lorenz M, Lüning K (1996) Influence of ultraviolet-radiation on chlorophyll fluorescence and growth in different life-history stages of three species of Laminaria (Phaeophyta). Mar Biol 126:183-191

Franklin LA, Forster RM (1997) The changing iradiance environment: consequences for marine macrophyte physiology, productivity and ecology. Eur J Phycol 32:207-232

Han T, Kain JM (1996) Effect of photon irradiance and photoperiod on young sporophytes of four species of the Laminariales. Eur J Phycol 31:233-240

Hanelt D, Melchersmann B, Wiencke C, Nultsch W (1997a) Effects of high light stress on photosynthesis of polar macroalgae in relation to depth distribution. Mar Ecol Prog Ser 149:255-266

Hanelt D, Wiencke C, Nultsch W (1997b) Influence of UV radiation on photosynthesis of Arctic macroalgae in the field. J Photochem Photobiol B 38:40-47

Henry BE, van Alstyne KL (2004) Effects of UV radiation on growth and phlorotannins in Fucus gardneri (Phaeophyceae) juveniles and embryos. J Phycol 40:527-533

Jacobsen S, Lüning K, Goulard F (2003) Circadian changes in relative abundance of two photosynthetic transcripts in the marine macroalga Kappaphycus alvarezii (Rhodophyta). J Phycol 39:888-896

Johansson G, Snoeijs P (2002) Macroalgal photosynthetic responses to light in relation to thallus morphology and depth zonation. Mar Ecol Prog Ser 244:63-72

Littler MM, Littler DS (1980) The evolution of thallus form and survival strategies in benthic marine macroalgae: field and laboratory tests of a functional form model. Am Nat 116:25-44

Long SP, Humphries S, Falkowski PG (1994) Photoinhibition of photosynthesis in nature. Annu Rev Plant Physiol Plant Mol Biol 45:633-662

Lüder UH, Clayton MN (2004) Induction of phlorotannins in the brown macroalga Ecklonia radiata (Laminariales, Phaeophyta) in response to simulated herbivory-the first microscopic study. Planta 218:928-937 
Lüning K (1979) Growth strategies of three Laminaria species (Phaeophyceae) inhabiting different depth zones in the sublittoral region of Helgoland (North Sea). Mar Ecol Prog Ser $1: 195-207$

Lüning K (1985) Meeresbotanik: Verbreitung, Ökophysiologie und Nutzung der marinen Makroalgen. Georg Thieme Verlag, Stuttgart, pp 375

Lüning K (1992) Day and night kinetics of growth rate in green, brown, and red seaweeds. J Phycol 28:794-803

Lüning K (1994) Circadian growth rhythm in juvenile sporophytes of Laminariales (Phaeophyta). J Phycol 30:193-199

Lüning K (2001) Circadian growth in Porphyra umbilicalis (Rhodophyta): spectral sensitivity of the circadian system. J Phycol 37:52-58

Pascal A, Gradinaru C, Wacker U, Peterman E, Calkoen F, Irrgang K-D, Horton P, Renger G, van Grondelle R, Robert B, van Amerongen $H$ (1999) Spectroscopic characterization of the spinach Lhcb4 protein (CP29), a minor light-harvesting complex of photosystem II. Eur J Biochem 262:817-823

Pavia H, Toth G, Aberg P (1999) Trade-offs between phlorotannin production and annual growth in natural populations of the brown seaweed Ascophyllum nodusum. J Ecol 87:761-771

Poppe F, Hanelt D, Wiencke C (2002) Changes in ultrastructure, photosynthetic activity and pigments in the Antarctic red alga Palmaria decipiens during acclimation to UV radiation. Bot Mar 45:253-261

Reed DC, Amsler CD, Ebeling AW (1992) Dispersal in kelps: factors affecting spore swimming and competency. Ecology 73:1577-1585

Robberecht R, Caldwell MM (1978) Leaf epidermal transmittance of ultraviolet radiation and its implications for plant sensitivity to ultraviolet-radiation induced injury. Oecologia (Berl) 32:277-287

Roleda MY, van de Poll WH, Hanelt D, Wiencke C (2004a) PAR and UVBR effects on photosynthesis, viability, growth and DNA in different life stages of two coexisting Gigartinales: implications for recruitment and zonation pattern. Mar Ecol Prog Ser 281:37-50

Roleda MY, Hanelt D, Kräbs G, Wiencke C (2004b) Morphology, growth, photosynthesis and pigments in Laminaria ochroleuca (Laminariales, Phaeophyta) under ultraviolet radiation. Phycologia 43:603-613

Roleda MY, Wiencke C, Hanelt D, van de Poll WH, Gruber A (2005a) Sensitivity of Laminariales zoospores from Helgoland (North Sea) to ultraviolet and photosynthetically active radiation: implications for depth distribution and seasonal reproduction. Plant Cell Environ 28:466-479

Roleda MY, Hanelt D, Wiencke C (2005b) Growth kinetics related to physiological parameters in young Saccorhiza dermatodea and Alaria esculenta sporophytes exposed to UV radiation. Polar Biol 28:539-549

Roleda MY, Wiencke C, Hanelt D (2006) Thallus morphology and optical characteristics affect growth and DNA damage by UV radiation in juvenile Arctic Laminaria sporophytes. Planta DOI 10.1007/s00425-005-0092-0

Schoenwaelder MEA (2002) The occurrence and cellular significance of physodes in brown algae. Phycologia 41:125-139

Schoenwaelder MEA, Clayton MN (1999) The presence of phenolic compounds in isolated cell walls of brown algae. Phycologia 38:161-166

Setlow RB (1974) The wavelengths in sunlight effective in producing skin cancer: a theoretical analysis. Proc Nat Acad Sci USA 71:3363-3366

Starr RC, Zeikus JA (1993) UTEX - the culture collection of algae at the University of Texas at Austin. J Phycol 29(Suppl):1-106

Steinberg PD (1995) Seasonal variation in the relationship between growth rate and phlorotannin production in the kelp Ecklonia radiata. Oecologia 102:169-173

Suzuki L, Johnson CH (2001) Algae know the time of day: circadian and photoperiodic programs. J Phycol 37:933-942

van de Poll WH, Eggert A, Buma AGJ, Breeman AM (2001) Effects of UV-B induced DNA damage and photoinhibition on growth of temperate marine red macrophytes: habitat-related differences in UV-B tolerance. J Phycol 37:30-37

van de Poll WH, Hanelt D, Hoyer K, Buma AGJ, Breeman AM (2002) Ultraviolet-B induced cyclobutane-pyrimidine dimer formation and repair in Arctic marine macrophytes. Photochem Photobiol 76:493-501

Vink AA, Bergen-Henegouwen JB, Nikaido O, Baan RP, Roza L (1994) Removal of UV-induced DNA lesions in mouse epidermis soon after irradiation. Photochem Photobiol 24:25-31

Wiencke C, Gómez I, Pakker H, Flores-Moya A, Altamirano M, Hanelt D Bischof K, Figueroa FL (2000) Impact of UV radiation on viability, photosynthetic characteristics and DNA of brown algal zoospores: implications for depth zonation. Mar Ecol Prog Ser 197:217-229

Wiencke C, Clayton MN, Schoenwaelder M (2004) Sensitivity and acclimation to UV radiation of zoospores from five species of Laminariales from the Arctic. Mar Biol 145:31-39 